\title{
Web based Human Resource Information System for Skill-set based Academic Training Process
}

\author{
Athithya E. \\ Senior Research Fellow \\ Combat Vehicle Research and \\ Development Establishment \\ Avadi, Tamilnadu, India
}

\author{
Kavitha A.C. \\ Technical Officer 'B' \\ Combat Vehicle Research and \\ Development Establishment \\ Avadi, Tamilnadu, India
}

\author{
S. Muralidhar, $\mathrm{PhD}$ \\ Scientist ' $G$ ' \\ Combat Vehicle Research and \\ Development Establishment \\ Avadi, Tamilnadu, India
}

\begin{abstract}
Combat Vehicle Research \& Development Establishment (CVRDE) is a centre for Design \& Development of state -of the -art Armoured Fighting Vehicles for the services. In order to make use of good talents from the educational institutions, organization extends its proficiency for Graduate/ Post Graduate in Engineering/ General Sciences students to carry out Academic Training [Internship/ Project Work] in the area of design and development which are useful to the organization. The focus of this paper is to present the web based self service portal for the Skill-set based Academic Training process. Experimental analysis revealed that the automated system improves transparency, traceability, ease of access, flexibility and also enhances the overall system efficiency.
\end{abstract}

\section{General Terms}

Human Resource (HR) Department Automation, Web Application, Digitization, Paperless Office.

\section{Keywords}

HR Personnel, Academic Training, HR service, Documents \& Reporting, Web based HR, Information System.

\section{INTRODUCTION}

Directorate of Human Resource Development (DHRD) provides the guidelines/ Statement of Procedure (SOP) for enrolling the students from Colleges/ Universities for Project Training (Internship/ Project Work) to DRDO Labs/ Establishments. The organization should strictly adhere to this guideline while processing the student application for project training. The Director of the concerned Lab/ Establishment is the only approving authority. The number of Project Trainees as well as officer who will guide the project trainees will be decided by the Director. Selection of appropriate students should be done by Committee constituting with Director/ representative and two other senior scientist. The Guide/ Supervisor have to ensure that the project training report generated by the trainee(s) under him/ her has quality contents and does not contain any classified information. Here the Human Resource (HR) department work [1,2] is to oversee the process and extend the logistic and administrative support to the trainees.

Along with DHRD guidelines, CVRDE follows some more additional procedures for project training in order to avoid inconvenience in the regular project activities. In this regard, the following eligibility criteria depicted in Table 1 and policies have been formulated for doing project training at CVRDE. The policies classified into 4 major categories.

1. CATEGORY I: The students studying in the following Colleges/ Institutions are eligible to apply i.e., IISC, IITs,
NITs, Government Institutions (State/ Union Owned), Autonomous Institutions (State/ Union Owned), Institutions run by Tri services and Institutions run by Autonomous body by DAE, CSIR/ ISRO/ Union/ State/ Institutions

2. CATEGORY II: Educational Institutions which is covering NAAC accreditation CGPA 3.01 and above (i.e., A and above) are eligible to apply.

3. CATEGORY III: CVRDE Employees Son/ Daughter mentioned in the service book are eligible to apply.

4. CATEGORY IV: Any institutions not covered in Categories I to II will be entertained based on the merit of the case and the approval of the Director, CVRDE.

Table 1. Eligibility Criteria

\begin{tabular}{|c|c|c|c|c|}
\hline $\begin{array}{c}\text { Student } \\
\text { Category }\end{array}$ & $\begin{array}{c}\text { Project } \\
\text { Training } \\
\text { Category }\end{array}$ & $\begin{array}{l}\text { Current } \\
\text { Semester }\end{array}$ & $\begin{array}{c}\text { Minimum } \\
\text { Duration }\end{array}$ & $\begin{array}{c}\text { Maximum } \\
\text { Number of } \\
\text { Student } \\
\text { allowed }\end{array}$ \\
\hline \multirow[t]{2}{*}{ U.G } & Internship & $\begin{array}{c}\text { Should } \\
\text { have } \\
\text { completed } \\
\text { 6th } \\
\text { Semester }\end{array}$ & 4 weeks & 4 \\
\hline & $\begin{array}{l}\text { Project } \\
\text { Work }\end{array}$ & $\begin{array}{c}\text { Should } \\
\text { have } \\
\text { completed } \\
7 \text { th } \\
\text { Semester }\end{array}$ & 3 months & 4 \\
\hline P.G & $\begin{array}{l}\text { Project } \\
\text { Work }\end{array}$ & $\begin{array}{c}\text { Should } \\
\text { have } \\
\text { completed } \\
\text { 2nd } \\
\text { Semester }\end{array}$ & 6 months & 1 \\
\hline
\end{tabular}

The following documents are mandatory while submitting the application

1. Recommendation/ Bonafide Letter from Head of the Department / Dean / Principal

2. CV/ Resume of the student

3. Photograph of the student (Softcopy for uploading)

4. NAAC Accreditation information (if applicable)

5. College ID Card Scanned copy

For screening process, students comes under Category IV are required to send an application along with mandatory documents, 15 days prior to the desired starting date of project either through mail/ post and for remaining category CVRDE employee can apply on behalf of students through Intranet online HRD portal. Employee can apply at the maximum of 1 
Internship and 1 project work per year. Whenever Director approves the application for project training, corresponding intimation will be send through email by HRD. On joining, student has to intimate the HR personnel for further processing. HR personnel are in charge to notify about the student(s) to Library (for book access), Security (for Authentication) and guide (for doing project training). Gate pass is issued by HR personnel for each student that should be kept safe by student till the project training duration. After the completion of project training, guide has to inform the completion information (Project Title and Duration) along with project report (soft copy) to HR department as well as hardcopy of the project report should be submitted to Library for record purpose. Thereafter, finally a certificate will be issued from HR division Head with the reference to guide completion letter. Figure 1 illustrates the overall flow of Skillset based Academic training.

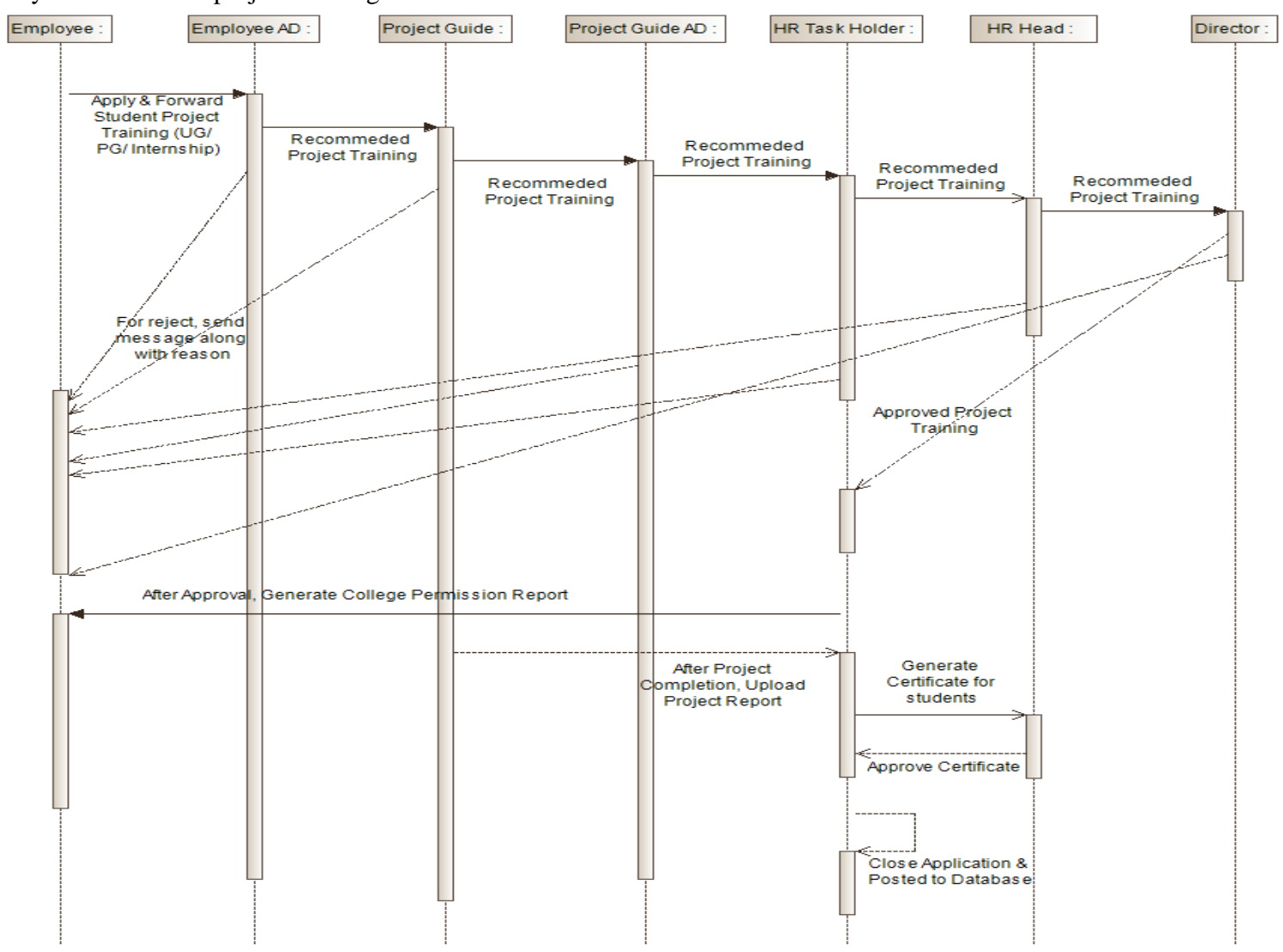

Fig 1: Overall flow of Skill-set based Academic Training

Aforesaid is the complete sequence of steps to be followed in existing manual system, it took lots of hard work, time, manual effort and paper work are required to do this process $[3,4]$. Recently, technology had made its own foot prints in each and every sector; HR department $[5,6]$ has undergone a paradigm shift in the day to day working environment by successive transformation of HR service delivery via web based self service application. Digital HR [7] is the process of automating the HR associated function to enhance the efficiency, effortless management, eliminates the need for preserving the humongous amount of paperwork, cutback a lot of effort, money and time of the HR department as well as employees. In addition, this software helps to look at the opportunities and the possible difficulties of HR technology [8]. This paper explains how the process has been incorporated in software and to what extend it can assist an employee and HR personnel for successful execution of process and lastly concludes with the progresses that made known evidently after the implementation of digitizing the Skill-set based Academic Training management process.

\section{SKILL-SET BASED ACADEMIC TRAINING SCHEME}

The web based self service application for Skill-set based Academic Training Scheme is for managing the project training workflow. This software allows end user to access HR service from anywhere and anytime inside the geographical location of CVRDE. Figure 2 describes the illustration of various end users who is interacting with this software for getting HR service. The viewing dashboard and the level of information access are completely based on the role and access rights of each stakeholder. 


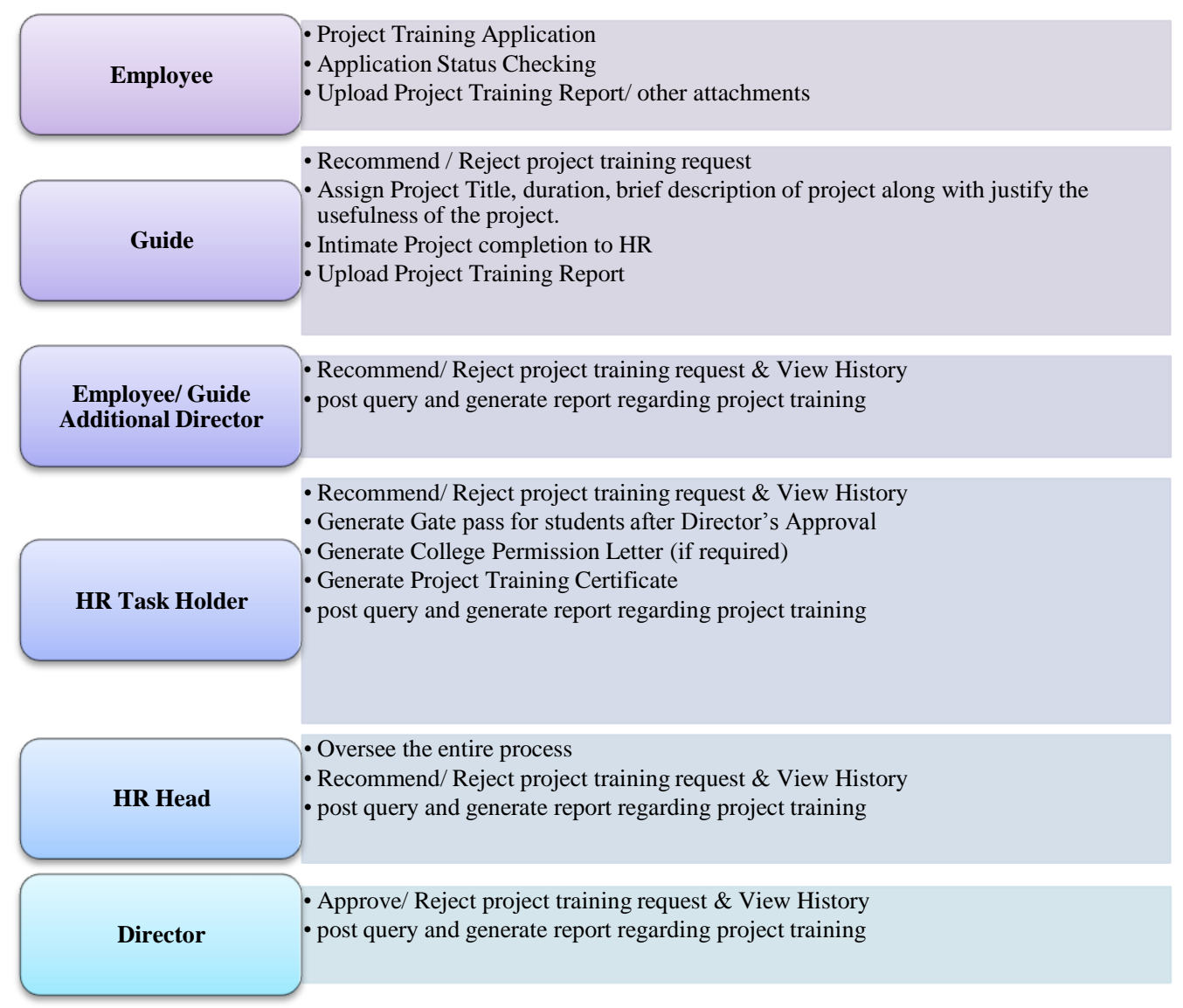

Fig 2: HRD Project Training Software accessed by various stakeholders

\subsection{EMPLOYEE}

The initial/ starting stakeholder is employee; he/she can initiate application for project training and will be routed to get approval from approver through online. While applying for project training employee should keep these things clear.

1) Employee should submit dependent information to administrator before going to apply for his/ her son/ daughter.

2) Employee also apply other than son/ daughter, in that case employee should clearly specify the relationship with the student

3) Employee should have the softcopy (PDF file) of mandatory documents and student photo (JPG/ JPEG file)

4) Employee can able to choose guide who is working under officer category alone.

Figure 3 shows the project training entry screen and the figure 4 illustrates the routing flow of the application. Employee can even track the application status which is shown in figure 5 and also having provision to re-upload the mandatory documents in case of finding inaccuracy in attached documents. Digitally signed application and declaration form have been generated after initial forwarding of application from employee which is shown in the figure 6 .

\subsection{EMPLOYEE/ GUIDE ADDITIONAL DIRECTOR}

Whenever employee raise an application it should be routed via his/ her authority likewise whenever guide accepts project training it should be informed and get approval from guide authority. Generally authority (Additional Director) should be responsible for subordinates so that they have to know about their subordinates activities. Figure 7 shows the sample screen of approver, the documents attached by the employee along with application are presented to approver to make decision regarding the application. 


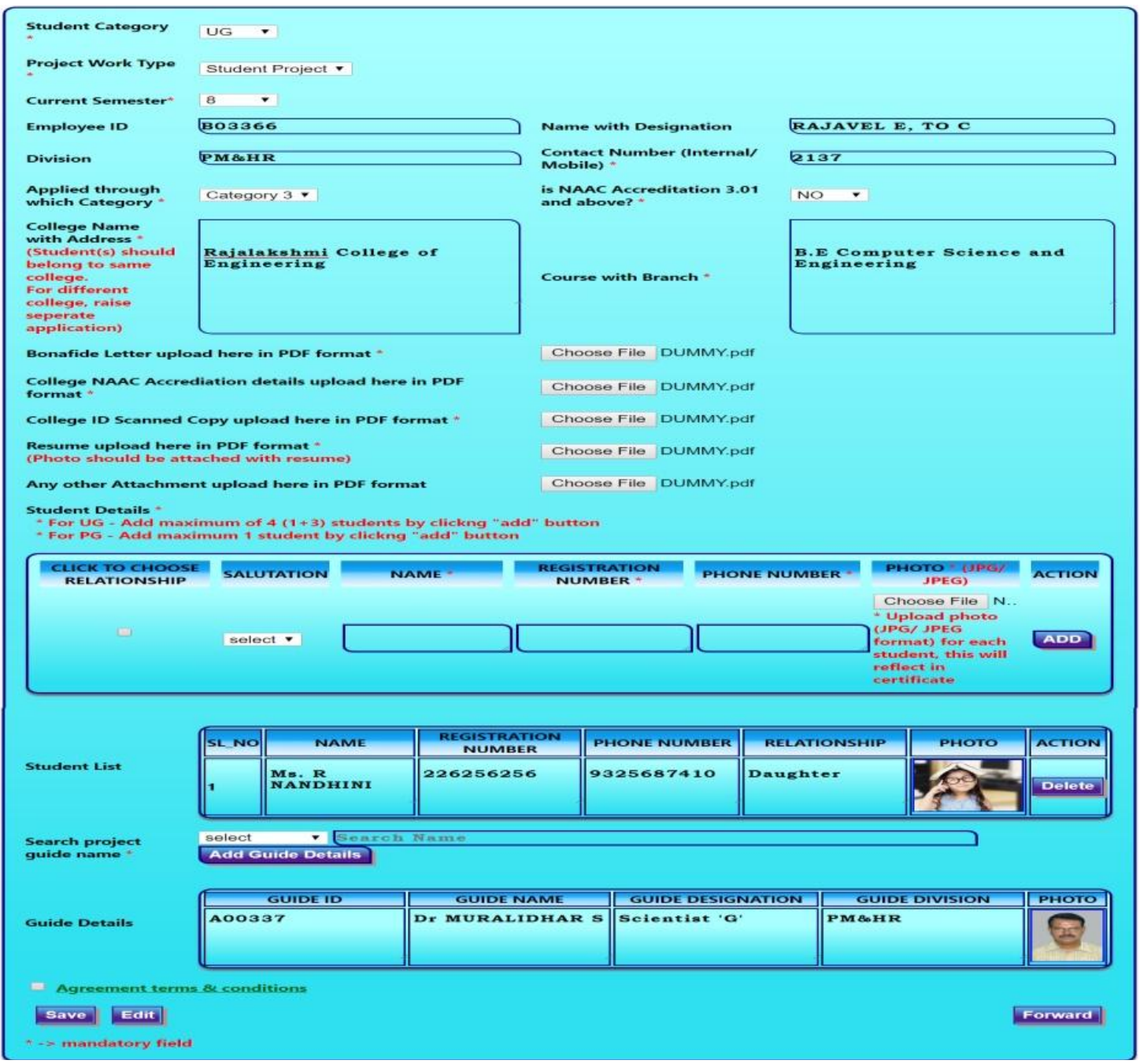

Fig 3: Project Training Entry Screen

\begin{tabular}{|c|c|c|c|c|c|c|c|c|c|c|c|c|}
\hline Employee & $-d$ & $\begin{array}{c}\text { Employee } \\
\text { Additional } \\
\text { Director }\end{array}$ & -2 & Guide & - & $\begin{array}{c}\text { Guide } \\
\text { Additional } \\
\text { Director }\end{array}$ & L & $\begin{array}{c}\text { HR Task } \\
\text { Holder }\end{array}$ & -3 & HR Head & -1 & Director \\
\hline
\end{tabular}

Fig 4: Project Training Routing Structure

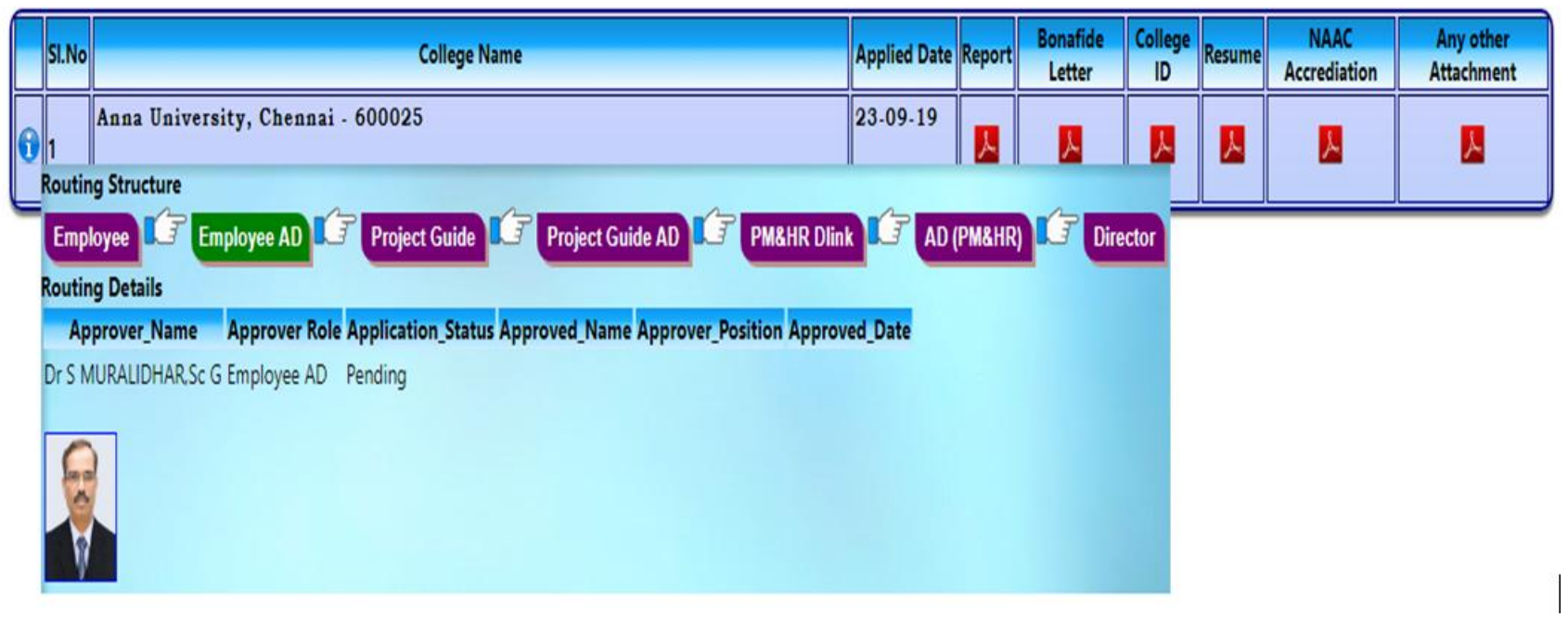

Fig 5: Project Training Application routing status tracking 


\begin{tabular}{|c|c|c|c|c|c|c|c|}
\hline \multicolumn{7}{|c|}{$\begin{array}{l}\text { Combat Vehicles Research \& Development Establishment (CVRDE) } \\
\text { DRDO, Ministry of Defence, } \\
\text { Chennai-54. } \\
\text { PROFORMA FOR STUDENTS PROJECT WORK U.G/P.G }\end{array}$} & 용 \\
\hline \multicolumn{3}{|c|}{ Employee ID } & \multicolumn{5}{|l|}{ B03437 } \\
\hline \multicolumn{3}{|c|}{ Employee Name with Designation } & \multicolumn{5}{|c|}{ PTHANGARAJU, TOC } \\
\hline \multicolumn{3}{|c|}{ Employee Division } & \multicolumn{5}{|l|}{ Admin } \\
\hline \multicolumn{3}{|c|}{ Contact Number (Internal/ Mobile) } & \multicolumn{5}{|c|}{$2237 / 9283224488$} \\
\hline \multicolumn{8}{|c|}{ Student Details } \\
\hline $\begin{array}{l}\text { SL. } \\
\text { No }\end{array}$ & STUDENT NAME & \multicolumn{2}{|c|}{ REGISTRATION NO } & PHONE NO & Рното & \multicolumn{2}{|c|}{ RELATIONSHIP } \\
\hline 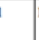 & AS. T SANGEETHA & \multicolumn{2}{|c|}{2015239014} & 8680999206 & 2 & \multicolumn{2}{|c|}{ Daughter } \\
\hline \multicolumn{8}{|c|}{ College \& Project Details } \\
\hline \multicolumn{3}{|c|}{ College Name } & \multicolumn{5}{|c|}{ College of Engineering. Guindy } \\
\hline \multicolumn{3}{|c|}{ Course with Branch } & \multicolumn{5}{|c|}{ M.Sc (Computer Science) } \\
\hline \multicolumn{8}{|c|}{ Current Semester } \\
\hline \multicolumn{3}{|c|}{ Student Project Category } & \multicolumn{5}{|l|}{ Student Project } \\
\hline \multicolumn{3}{|c|}{ Project Guide } & \multicolumn{5}{|c|}{ Smt. SELVATHAI T, Scientist 'E', VE } \\
\hline \multicolumn{3}{|c|}{ Project Title } & \multicolumn{5}{|c|}{ Graphical User Interface Using ROS } \\
\hline \multicolumn{3}{|c|}{ Project Work Duration } & \multicolumn{5}{|c|}{ 10-05-19 to $07-06-19$} \\
\hline \multicolumn{3}{|c|}{ Brief write up of the Project } & \multicolumn{5}{|c|}{ Develop a driver's dashboard display } \\
\hline \multicolumn{3}{|c|}{$\begin{array}{l}\text { Justification/ Usefulness of the } \\
\text { Project to CVRDE }\end{array}$} & \multicolumn{5}{|c|}{$\begin{array}{l}\text { The project will be useful for the current Teleoperated Dozer project } \\
\text { and for future projects }\end{array}$} \\
\hline
\end{tabular}

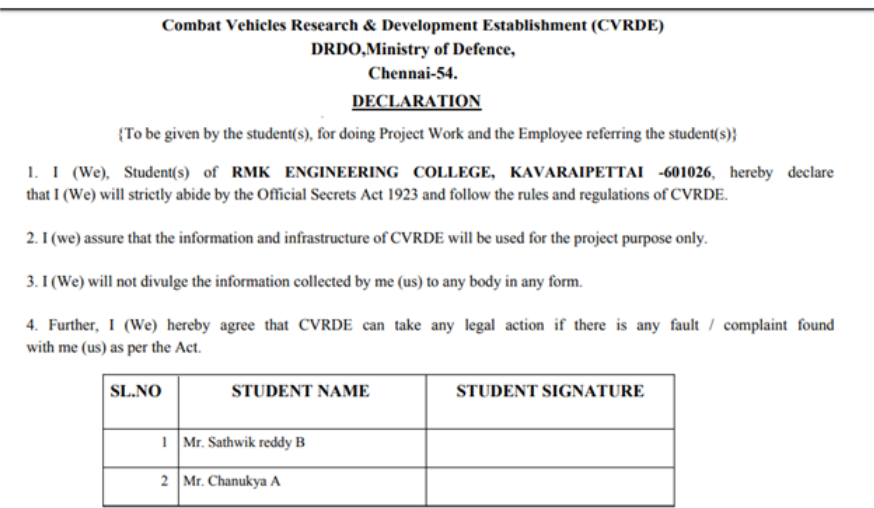

Fig 6: Project Training Application \& Declaration Form

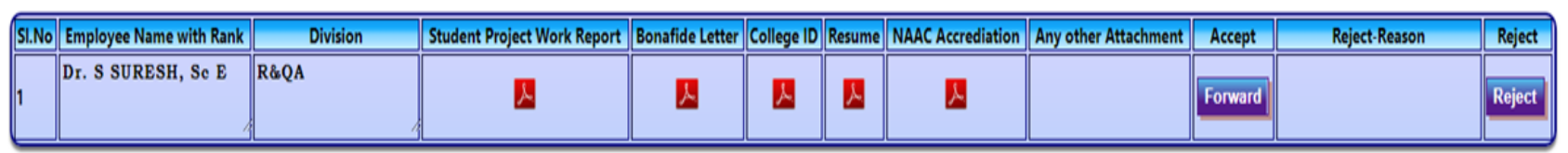

Fig 7: Project Training Application - Approval Screen

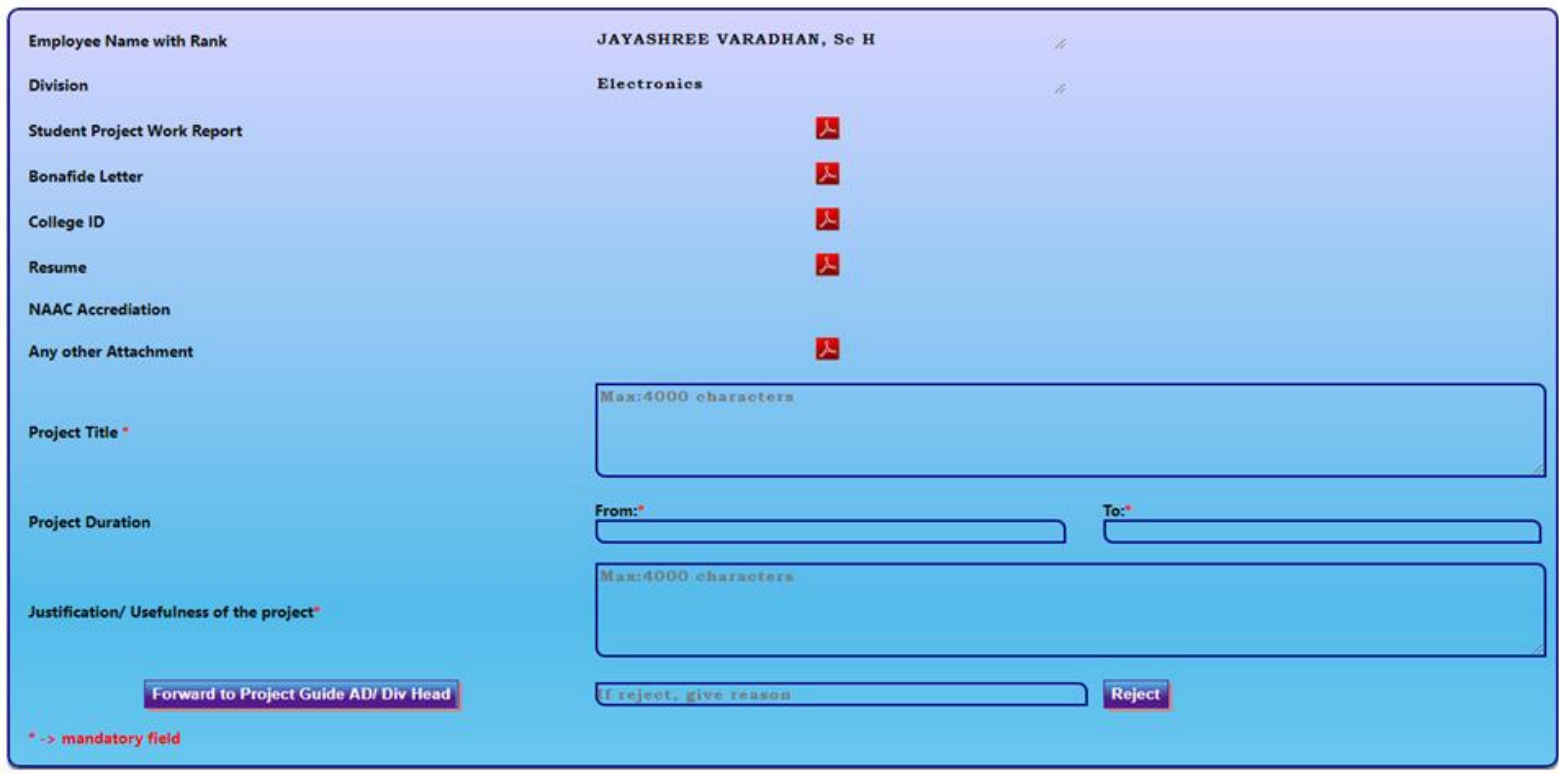

\subsection{GUIDE}

Guide will decide whether to accept/ reject the application based on the availability that would not affect the regular work. Guide sample screen is displayed in figure 8 . These are the following actions can be done by guide while guiding the project training.

1) For application accept, guide has to provide project title, duration of project, brief description of the project and writeup about how the project is useful to the organization. For reject, valid reason should be given
Fig 8: Project Training Application - Guide Approval Screen

2) Guide having provision to intimate the project completion along with project report (PDF file) to HR task holder

\subsection{TASK HOLDER}

The role of task holder is to oversee the entire process and extend the logistic and administrative support to the students. Guide additional director recommended application will be routed to HR Head via HR task holder. Task holder is responsible for verifying the correctness of the mandatory documents and recommended the eligible application to HR Head. In addition to that, administrative process for project training like providing gate pass for students, intimating 
student's tenure detail to security and library, upload project report, generate certificate and finally post the application information to database.

\subsection{HR HEAD}

The information presented will be same as Employee/ guide Additional director's approval screen. Here HR task holder recommended application will be listed along with mandatory documents. HR Head will decide whether to recommend/ reject the application. Recommended application will go Director for final approval and for rejection, the information will be intimated to employee along with reason for rejecting the application. Additional provision also provided to post query and generate report regarding project training.

\subsection{DIRECTOR}

Finally, Director of the Lab/ Establishment having the authority to decide whether to approve/ reject, the information presented in the Director screen will be same as Employee/ Guide Additional director's/ HR Head approval screen. Additional provision also provided to post query and generate report regarding project training.

\section{RESULTS AND DISCUSSION}

The web based self service portal was implemented using ASP.NET Model View Controller (MVC) 4 framework with ASP.NET 4.5 , Razor Engine [9], JavaScript library jQuery $[10,11]$ and AJAX for User Interface and ORACLE 11g for database. ASP.NET MVC offers a fully operational framework that applies model- view- controller prototype for constructing an interactive user interface. MVC offers imperative features for developers such as improvised debugging functionality, enlarge its support to carry out team/ group work on the particular project by comprehensible separation of application. Oracle11g [12] is used for database related activities. It stores information (i.e., text, image, graphics, audio, video and documents), indexes, procedures and triggers. When the table is using indexing Oracle $11 \mathrm{~g}$ gives faster result for queries. Database procedure helps to perform essential action/data processing of the application. Furthermore, SAP Crystal report software was used to generate report whenever and wherever required. The end user/ stakeholder interact with application via a web browser (Mozilla Firefox/ Chrome). The communication is established between database and application on need basis and passes data to the stakeholder. Table 2 shows the number of students gets trained from organization after implementing the online portal.

Table 2. Number of students trained for each year

\begin{tabular}{|l|c|}
\hline \multicolumn{1}{|c|}{ Year \& Month } & $\begin{array}{c}\text { No. of Students } \\
\text { Trained }\end{array}$ \\
\hline $\begin{array}{l}2019 \text { (From January to } \\
\text { September) }\end{array}$ & 87 \\
\hline $\begin{array}{l}2018 \text { (From August to } \\
\text { December) }\end{array}$ & 37 \\
\hline
\end{tabular}

For analyzing the overall quality of web based self service application, performance analysis has been carried out with existing manual system by considering the essential metrics such as amount of paperwork required and time duration for application approval. Figure 9 shows the average time taken by the system at each stage of approving process and at the end it concludes with overall time consumed by the system individually. In manual, additional approval time is taken by administrator to verify employee's dependent information, that processing time is eradicated in computerized system by automatically checking the dependent information for admin database.

Figure 10 depicts the minimum amount of paperwork required at each stage in order to accomplish the complete process. From that graph, it is evident that the proposed system requires least level of documentation. In addition to that, computerized system cut out the paperwork maintained for application and supporting documents by uploading the soft copy of mandatory documents in database at the time of application initiation. The example case considers here is processing project work for 4 students.

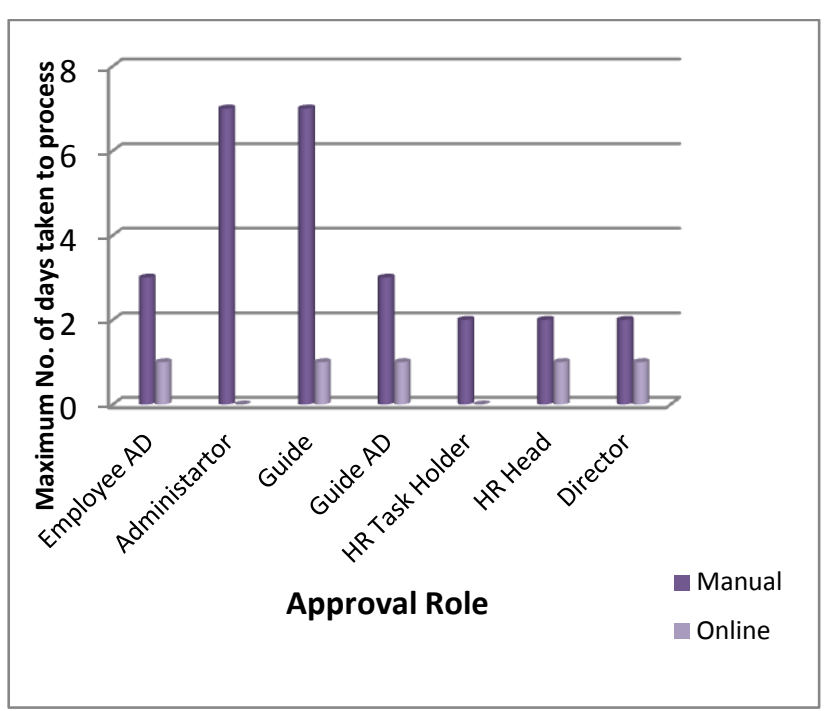

Fig 9: Time duration for application approval

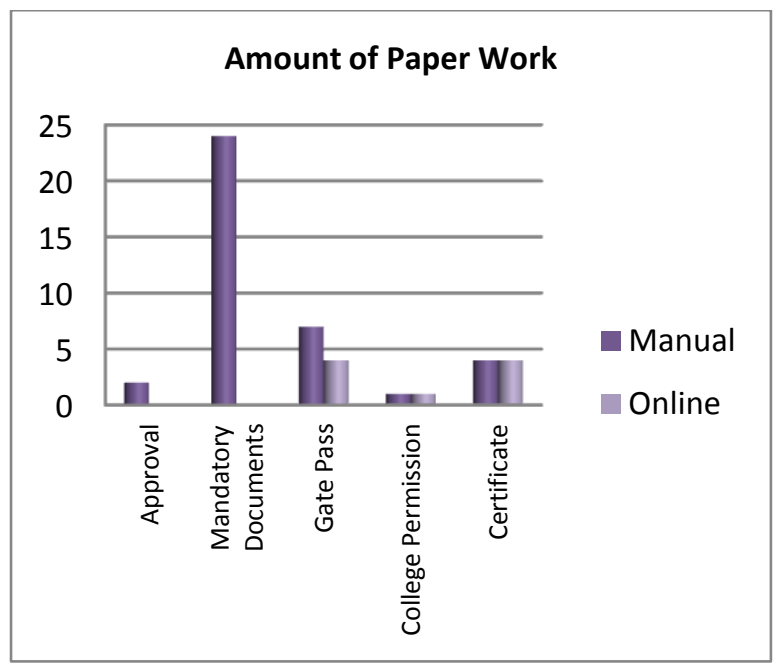

Fig 10 Amount of paper work required

\section{CONCLUSION}

Online web application for Skill-set based Academic Training has been successfully implemented in CVRDE from August 2018 onwards. Analysis had been carried out to evaluate the existing manual system with computerized system. From the outcome, it is clear that the computerized process has noticeable impact in the overall quality of work, immensely reduce the decision making time and improves the communication between employee and HR department. Furthermore, this software significantly reduces the physical 
storage space, facilitates effortless tracking of records and provides optimum recovery of data in case of hazard.

\section{REFERENCES}

[1] Society for Human Resource Management. 2005. Online assessments speed candidate selection process.

[2] Cedar, Crestone. 2010 HR Systems Survey, 12th Annual Edition.

[3] Johnson, R. D. and Yanson, R. C. 2010. E-learning research: Integrating findings from human resources, management information systems, and education. In K.Lukaszewski \& D. L. Stone (Chairs), Emerging Issues in Research on Electronic Human Resource Management Systems. Symposium at the 70th Annual Meeting of the Academy of Management, Montreal.

[4] Robb, D. 2010. Making the move to manager selfservice. HR Magazine 55(11), 67-68.

[5] Kazakovs, M. 2014. Analysis of Factors Influencing the Choice of Solutions for Human Resource Development. Elsevier Procedia - Social and Behavioral Sciences. 156, 111-115.

[6] Maksims, Kazakovsa. Anta, Verdinaa. and Irina,
Arhipovab. 2015. Automation of Human Resources Development Planning. Elseiver Procedia Computer Science. 77, $234-239$.

[7] Li, Song and Jing, Li. 2018. Building HR Information Modeling and Risk Management: A Bayesian Networks Approach. In 2nd IEEE Advanced Information Management, Communicates, Electronic and Automation Control Conference (IMCEC 2018), pp. 2001- 2004.

[8] Nishad, Nawaz. 2012. Human Resource Information Systems-A Review. International Journal of Management, IT and Engineering, 2(6), 402-416.

[9] Jess, Chadwick. 2011. Programming Razor. O'Relly Media, Inc.

[10] Jonathan, Chaffer. and Karl, Swedberg. 2013. Learning jQuery Fourth Edition. Packt Publishing.

[11] Suprotim, Agarwal. 51 Tips, Tricks and Recipes with jQuery and ASP.NET Controls. A2Z Knowledge Visuals Pvt. Ltd.

[12] Bob, Bryla. 2008. Oracle Database 11g- DBA Handbook. Tata McGraw-Hill. 